\title{
ALARM FIRE DETECTION WITH GUI
}

\author{
Asep Saefullah ${ }^{1}$ \\ Sudaryono ${ }^{2}$ \\ e-mail : asep@faculty.raharja.ac.id, sudaryono@faculty.raharja.ac.id
}

Diterima : 10 Maret 2011/Disetujui : 24 Maret 2011

\begin{abstract}
Lately frequent catastrophic fires with a variety of reasons, and that an obstacle is delay in the arrival of firefighters that can cause big losses. This delay is caused by a lack of information quickly to local fire until the fire department and is not known exactly where the fire occurred. To solve these problems then designed a system that can display information on fire location on the PC (Personal Computer) so that the information obtained in real time. AT89S52 microcontroller is an IC (Integrated Circuit) used as an interface between the receiver and transmitter that is connected to the computer. In this design, receiver and transmitter that used the IC SM6135 and SM6136. For data communication between a PC with the interface then created a program using Visual Basic 6.0. The result of this design is a prototype that can simulate fires that occur in real time and displays it through a GUI (Graphical User Interface).
\end{abstract}

Keywords: Fire Alarm Detector, AT89S52 Microcontroller, GUI

\section{ABSTRAKSI}

Akhir-akhir ini sering terjadi bencana kebakaran dengan berbagai sebab, dan yang menjadi kendala adalah terlambatnya kedatangan petugas pemadam kebakaran sehingga dapat menimbulkan kerugian yang besar. Keterlambatan ini disebabkan oleh kurang cepatnya informasi kebakaran sampai kepada instansi pemadam kebakaran dan tidak diketahui dengan tepat di mana lokasi kebakaran tersebut terjadi. Untuk memecahkan permasalahan tersebut maka dirancang suatu sistem yang dapat menampilkan informasi letak lokasi kebakaran pada PC (Personal Computer) sehingga informasi diperoleh secara real time.

1. Dosen Jurusan Sistem Komputer, STMIK Raharja

J1. jend Sudirman No. 40 Modern Cikokol-Tangerang Telp. 5529692

2. Dosen Jurusan Sistem Komputer, STMIK Raharja

Jl. jend Sudirman No. 40 Modern Cikokol-Tangerang Telp. 5529692 
Mikrokontroler AT89S52 merupakan suatu IC (Integrated Circuit) yang digunakan sebagai interface antara receiver dan transmitter yang dihubungkan pada komputer. Pada rancangan ini receiver dan transmitter yang digunakan menggunakan IC SM6135 dan SM6136. Untuk komunikasi data antara PC dengan Interface maka dibuat suatu program menggunakan Visual Basic 6.0. Hasil dari rancangan ini adalah suatu prototype yang dapat mensimulasikan kebakaran yang terjadi secara real time dan menampilkannya melalui GUI (Graphical User Interface).

Kata kunci : Alarm Pendeteksi Kebakaran, Mikrokontroller AT89S52, GUI

\section{PENDAHULUAN}

Perkembangan teknologi yang sangat pesat yang diiringi oleh kemajuan teknologi digital di era globalisasi dan modernisasi sekarang, segala bidang relatif bisa dipandang sangat relevan berhubungan dengan komputer. Tidak menutup mata betapa sangat berpengaruhnya komputer terhadap kemajuan zaman, baik dari segi kuantitas dan kualitas bagi kepentingan manusia. Teknologi komputer merupakan solusi yang dapat dimanfaatkan untuk mengatasi biaya, serta menjadi model yang fleksibel. Pesatnya perkembangan dunia komputer akhir-akhir ini, memicu berkembangnya teknologi baru yang memanfaatkan teknologi komputer sebagai media untuk mewujudkan impian dan mempermudah pekerjaan manusia.

Komputer merupakan serangkaian ataupun sekelompok mesin elektronik yang terdiri dari ribuan bahkan jutaan komponen yang dapat saling bekerja sama, serta membentuk sebuah sistem kerja yang rapi dan teliti, yang akan sangat membantu manusia dalam menyelesaikan pekerjaanya secara efektif dan efisien.

Dalam kehidupan sehari-hari, sering dijumpai bencana-bencana yang terjadi pada kehidupan di masyarakat. Salah satu yang menjadi ketakutan pada masyarakat, pemilik perusahaan dan pada instansi-instansi pemerintahan yaitu bencana kebakaran, yang merupakan salah satu bencana yang sangat merugikan.

Dengan melihat bencana kebakaran yang sering terjadi dikehidupan masyarakat, instansi-instansi maupun para pemilik perusahaan, maka dicari suatu pemecahan dari masalah tersebut. Dalam penelitian ini mencoba membahas aspek pendukung dalam upaya mengetahui tempat berlangsungnya kejadian kebakaran yang tentunya dapat membantu dan meringankan beban manusia dalam mengurangi 
korban jiwa dan kerugian secara materil jika terjadi kebakaran pada suatu tempat (rumah/gedung).

Dugaan sementara untuk dapat memecahkan masalah tersebut maka dibuatkan sebuah sistem yang dapat mendeteksi kebakaran secara dini, dengan tujuan dapat memberikan informasi berupa penampil lokasi kebakaran serta nama ruangan yang dapat dimonitoring langsung oleh petugas yang bersangkutan. Penggunaan alat ini semakin dibutuhkan, dengan semakin kompleksnya pekerjaan manusia dan tingginya faktor terjadinya kebakaran.

\section{PERMASALAHAN}

Berdasarkan latar belakang dan pengamatan yang dilakukan, maka dapat diuraikan beberapa permasalahan yang dihadapi, antara lain:

1. Bagaimanakah cara untuk petugas pemadam kebakaran dapat mengetahui lokasi / ruangan bila terjadi kebakaran di suatu tempat?

2. Bagaimana merancang suatu alat pendeteksi kebakaran serta dapat memberikan informasi dan tampilan lokasi / ruangan kepada petugas pemadam kebakaran yang di paralel ke pusat monitoring sistem.

3. Bagaimanakah membuat program monitoring "Alarm Detection With GUI", yang dapat menampilkan simulasi pada layar monitor.

\section{HASIL DAN PEMBAHASAN}

Pada perancangan ini terdiri dari dua perangkat, yaitu perangkat keras (Hardware) dan perangkat lunak (Software). Perangkat keras merupakan rangkaian elektronika yang terdiri dari rangkaian catu daya, mikrokontroller, dan rangkaian sensor, perangkat lunaknya merupakan program assembly. Pada bagian pembahasan ini, kedua perangkat tersebut akan dibahas secara terpisah.

\section{Perangkat Keras (Hardware)}

Personal Computer (PC) Rangkaian Mikrokontroler AT89S52 Dekoder Rangkaian Penerima Sensor Enkoder Rangkaian Pengirim Agar mempermudah dalam melakukan pembahasan dan memahami kinerja rancangan alat, maka dapat dilihat pada diagram blok rangkaian berikut : 


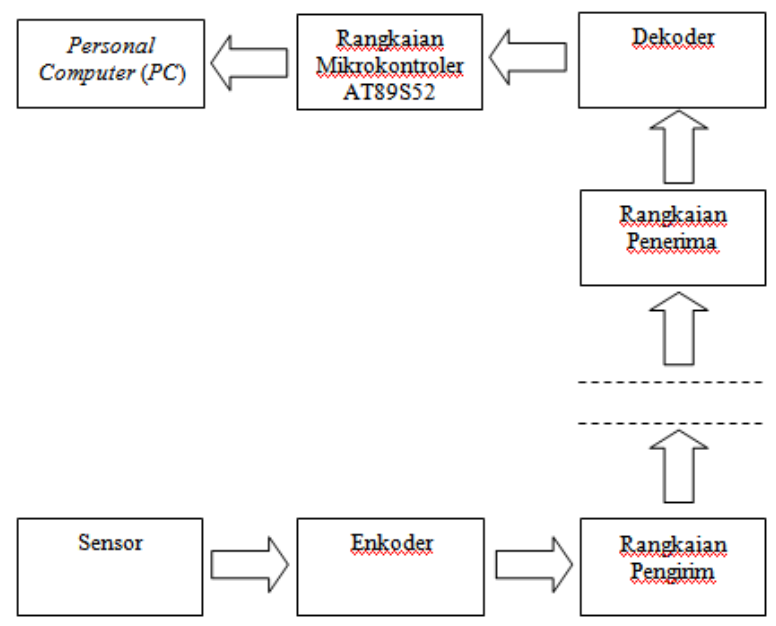

Gambar 1. Diagram Blok Rangkaian Alarm Detection With GUI

Rancangan tampilan dengan menggunakan mikrokontroler AT89S52 pada intinya menggunakan tiga bagian utama yaitu: indikator, mikrokontroler AT89S52 dan tampilan sebagai media penunjuk. Rancangan ini berfungsi sebagai alat tambahan penunjukan ruangan yang lebih spesifik, apabila terjadi kebakaran disalah satu gedung tampilan yang terdapat pada monitor akan menunjukkan ruangan dan nama ruangan yang terbakar.

\section{Rangkaian Sensor}

Rangkaian ini terdiri dari empat buah LED sebagai pemberi sinyal pada LDR serta sebagai indikator dan empat buah LDR (Light Emited Diode) yang merupakan simulasi dari smoke detector yang berada ditiap-tiap ruangan / gedung dan satu buah potensio meter $20 \mathrm{~K} \&$ ! yang berfungsi sebagai pengatur sensitifitas smoke detector.

Rangakaian ini berfungsi sebagai potensio logika untuk masukan rangkaian ke mikrokontroler AT89S52. Dengan cara apabila potensio meter ini di putar ke kanan searah jarum jam, maka potensio ini akan menghasilkan tegangan yang apabila tegangan tersebut melebihi tegangan yang sudah diatur sensitifitasnya oleh potensio meter, karena tegangan yang dihasilkan oleh sensor sangat kecil maka digunakan IC LM 324 yang berfungsi sebagai comparator tegangan yang dihasilkan dari sensor tersebut. 
IC LM 324 sebagai comparator mendapatkan masukan berupa tegangan dari smoke detector dan tegangan ini dijadikan sebagai tegangan reverensi, tetapi tegangan ini dapat diatur dengan menggunakan trimpot sebesar $20 \mathrm{~K} \&$ !. Apabila input Op-Amp mendapat tegangan lebih besar dari tegangan reverensi maka outputnya menjadi tegangan 0 Volt atau logika 0 . Ini disebabkan karena inputan terhubung ke kaki inverting Op-Amp sehingga outputnya kebalikan dari inputnya. Pada saat Op-Amp tidak dapat inputan maka nilai tegangan pada kaki non inverting lebih besar dari pada nilai tegangan pada kaki inverting, sehingga output dari OpAmp menghasilkan nilai tegangan +5 Volt atau logika 1 .

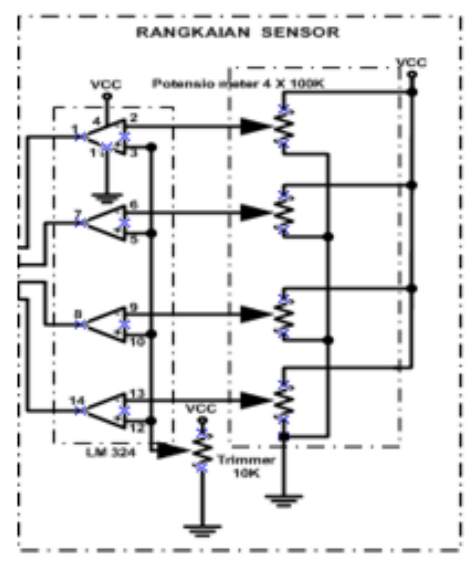

Gambar 2. Rangkaian Sensor (Indikator)

Indikator ini akan terhubung ke Port 0 mikrokontroler yaitu:

- Port 0.0 menunjukan nama ruangan/lokasi Ruang 1

- Port 0.1 menunjukan nama ruangan/lokasi Ruang 2

- Port 0.2 menunjukan nama ruangan/lokasi Ruang 3

- Port 0.3 menunjukan nama ruangan/lokasi Ruang 4

Pin 0 sampai pin 3 yang dijadikan sebagai masukan berlogika satu (High), dan pin 4 sampai pin 8 tidak digunakan maka port ini dihubungkan ke ground.

\section{Rangkaian Kontrol}

Sistem kontrol pada rangkaian ini menggunakan mikrokontroler AT89S52 yang merupakan tempat pengolahan data dan pengoperasian alat. Dalam rancangan ini mikrokontroler ini berfungsi sebagai pusat dari seluruh sistem. Mikrokontroler ini mempunyai delapan buah port, tetapi disini hanya digunakan empat buah port yang 
dipakai sebagai simulasi.Empat buah port ini digunakan untuk menampung masukan atau keluaran data.

Tabel 1. Data Inputan Mikrokontroler

\begin{tabular}{|c|c|c|}
\hline NO & INPUT BINER & INPUT HEX \\
\hline 1. & 0000.1111 & A \\
\hline 2. & 0000.1110 & B \\
\hline 3. & 0000.1101 & C \\
\hline 4. & 0000.1100 & D \\
\hline 5. & 0000.1011 & E \\
\hline 6. & 0000.1010 & F \\
\hline 7. & 0000.1001 & G \\
\hline 8. & 0000.1000 & H \\
\hline 9. & 0000.0111 & I \\
\hline 10. & 0000.0110 & J \\
\hline 11. & 0000.0101 & K \\
\hline 12. & 0000.0100 & L \\
\hline 13. & 0000.0011 & M \\
\hline 14. & 0000.0010 & N \\
\hline 15. & 0000.0001 & N \\
\hline 16 & 0000.0000 & O \\
\hline
\end{tabular}

- Pin XTAL1 dan XTAL2, sumber detak mikrokontroler ini digunakan sumber detak internal yang menggunakan kristal 11,0592 MHz dan dua buah kapasitor $33 \mathrm{pF}(\mathrm{C} 1$ dan $\mathrm{C} 2$ ) yang diparalel dengan kristal. Kristal dan kapasitor dipasang pada kaki XTAL1 sebagai masukan dan XTAL2 keluaran dan berfungsi untuk menstabilkan frekuensi.

- Mikrokontroler menyediakan sarana reset yang terletak pada pin 9. kapasitor $10 \mathrm{mF}$ dan resistor 680\&! akan mereset rangkaian mikrokontroler. Reset dapat dilakukan dengan cara manual maupun otomatis saat power diaktifkan (Power On Reset). Saat terjadi reset isi dari register akan berubah. Reset akan terjadi dengan adanya logika 1 selama minimal 2 cycle pada kaki RST. Setelah kondisi pin RST kembali low, mikrokontroler akan mulai menjalankan program dari 
alamat $0000 \mathrm{H}$. Kondisi pada internal RAM tidak terjadi perubahan selama reset.

- Untuk mengaktifkan memori internal pada mikrokontroler AT89S52 maka kaki EA (External Acces Enable) harus dihubungkan ke VCC.

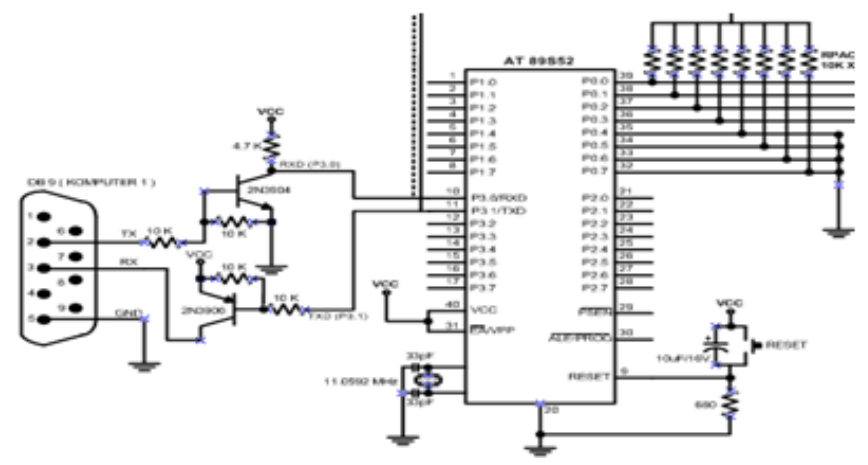

Gambar 3. Rangkaian Mikrokontroller

Rangkaian penerima pada perancangan ini menggunakan IC SM6136. IC ini digunakan untuk dapat menerima sinyal yang kemudian akan diberikan ke mikrokontroler, sinyal ini dikirim menggunakan media nirkabel.

\section{Tampilan}

Pada tampilan ini digunakan bahasa pemograman Visual Basic 6.0 sebagai penampil lokasi kebakaran yang dikirim oleh sensor. Bagian ini berfungsi untuk menampilkan status sensor, apakah sensor dalam kondisi normal atau dalam kondisi alarm. Tampilan yang dirancang terlihat seperti gambar berikut :

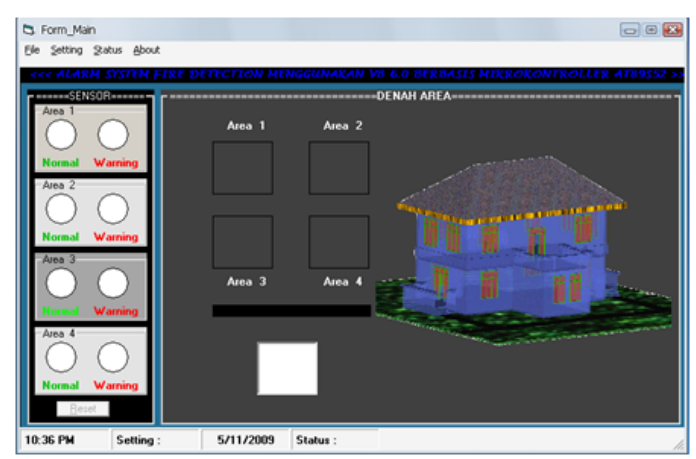

Gambar 4. Tampilan Pada Monitor 


\section{Perangkat Lunak (Software)}

Perangkat lunak pada mikrokontroler dibutuhkan untuk memberikan instruksiinstruksi pada mikrokontroler, sehingga mikrokontroler dapat bekerja sesuai dengan yang diinginkan. Dalam membuat suatu perangkat lunak / program pada mikrokontroler harus mengikuti prosedur-prosedur sesuai dengan ketentuan yang berlaku. Jadi agar mikrokontroler tersebut dapat bekerja untuk mendukung sistem peralatan seperti yang diinginkan, maka harus terlebih dahulu diisikan program assembly yang benar, baik dari segi bahasa program maupun cara pengisiannya.

\section{Pengisian program pada IC mikrokontroler AT89S52}

Sebelum mikrokontroler digunakan dalam sistem elektronika, harus terlebih dahulu diisikan program. Hal ini bertujuan agar IC tersebut dapat bekerja sesuai dengan yang diinginkan. Sedangkan hardwarenya menggunakan rangkaian penerjemah data, yang sebelumnya telah ditambahkan hubungan dengan konektor DB-25 sebagai penghubung dengan port PC.

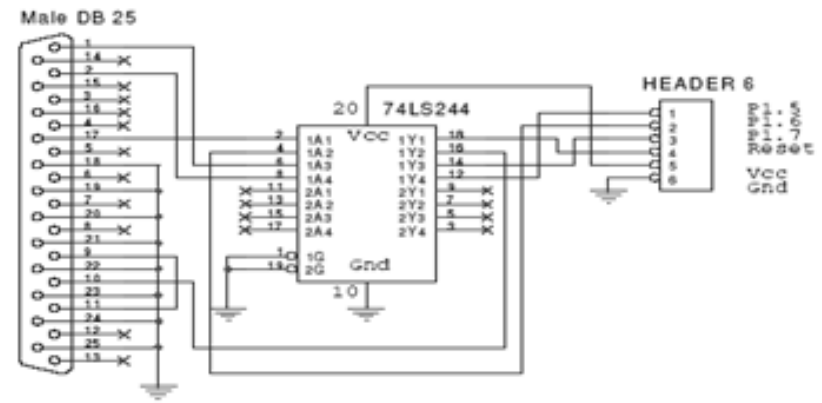

Gambar 5. Rangkaian Programmer ISP 89SXXX Konektor Male DB-25

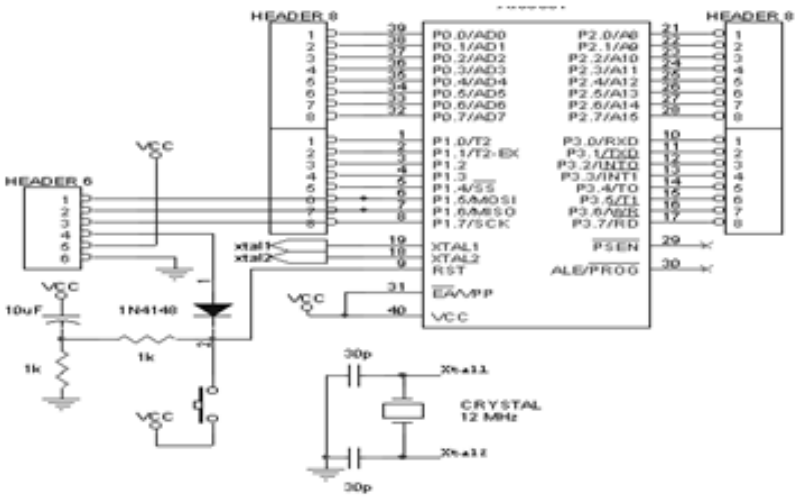

Gambar 6. Rangkaian Hardware Downloader Mikrokontroler 
Untuk memasukan program assembly dapat menggunakan software diatas dengan cara sebagai berikut:

a). Menuliskan daftar program pada text editor, semisal notepad dan microsoft word.

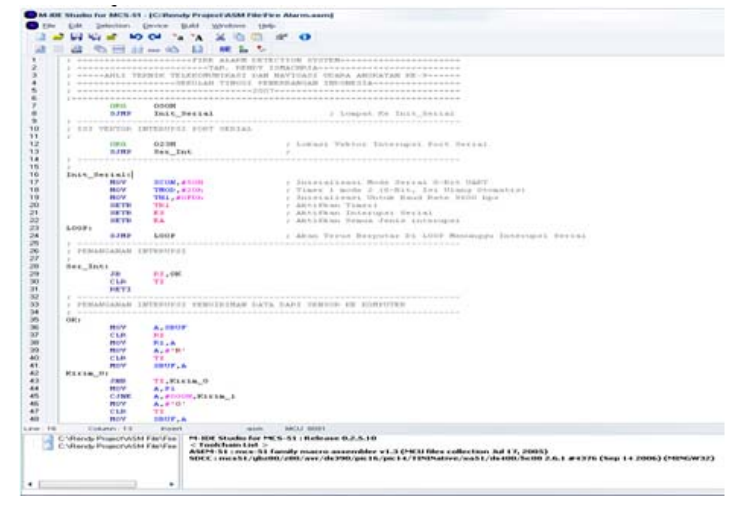

Gambar 7. Penulisan Daftar Program Pada Notepad

Setelah penulisan pada text editor selesai, kemudian text tersebut disimpan kedalam file dengan nama FPS.asm. Hal ini harus dilakukan karena software hanya bekerja pada file dengan nama asm. Bila file telah tersimpan maka akan tampak teks instruksi berwarna-warni seperti ditunjukan pada gambar diatas.

b). Mengubah (compile) bentuk file FPS.ASM menjadi FPS.HEX. Karena File HEX dapat di loadkan ke mikrokontroler.

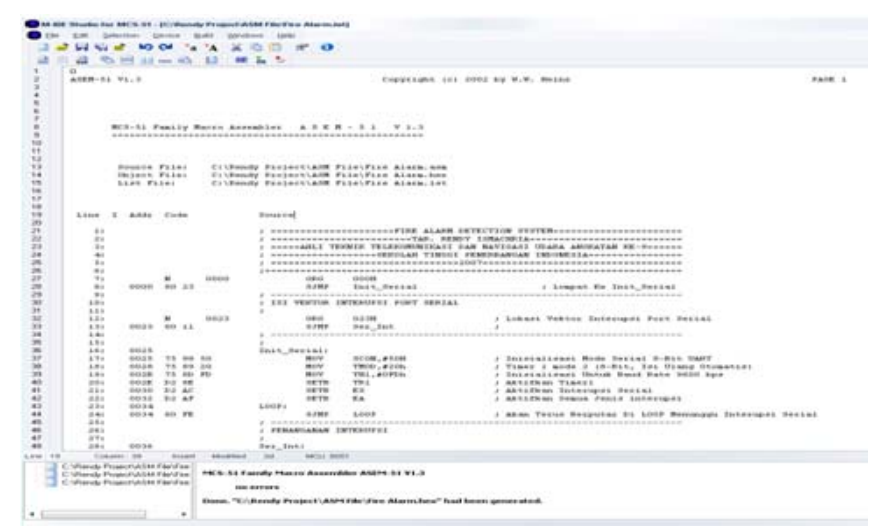

Gambar 8. Mengubah File FPS.asm Menjadi Fire Alarm HEX 
Setelah menuliskan file.asm yang akan dicompile pada software seperti pada gambar diatas, lalu diteruskan dengan memilih menu to compile file. Software mampu memberikan peringatan jika terjadi kesalahan pada proses ini, yang biasanya disebabkan karena kesalahan pada penulisan daftar program. Apabila tidak ada kesalahan pada penilisan daftar program, maka dibawah tampilan akan ada petunjuk no eror sebagai hasil dari perubahan tersebut. Seperti terlihat pada gambar dibawah ini.

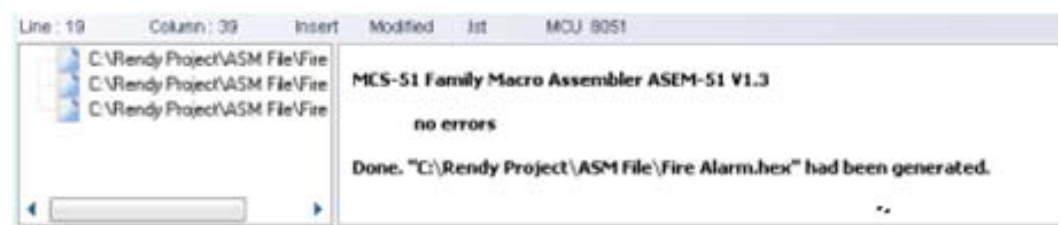

Gambar 9. File FPS.HEX Tidak Ada Yang Salah.

c). Memasukan file FPS.HEX kedalam IC mikrokontroler AT89S52. Pada langkah ketiga ini, IC mikrokontroler yang awalnya kosong mulai diisi dengan program. Sedangkan untuk IC yang sebelumnya telah terisi program lain, maka program tersebut dihapus dahulu sebelum diisi dengan program yang baru. Kedua program tersebut dilakukan secara otomatis oleh software yang ada. Untuk memulainya, buka terlebih dahulu program $A T M E L$ microcontroller ISP software. Kemudian pilih menu options, select device seperti terlihat pada gambar dibawah ini.

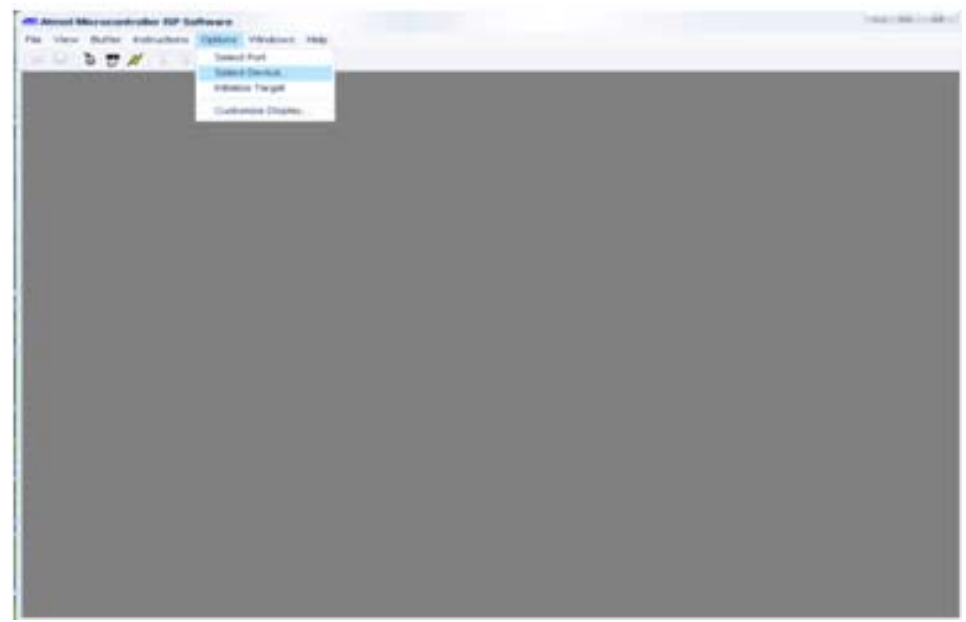

Gambar 10. ATMEL Microcontroller ISP Software 
Selanjutnya setelah memilih menu select device untuk memilih mikrokontroler tipe yang akan diisi program. Selanjutnya memilih mikrokontroler AT89S52 seperti terlihat pada gambar dibawah ini.

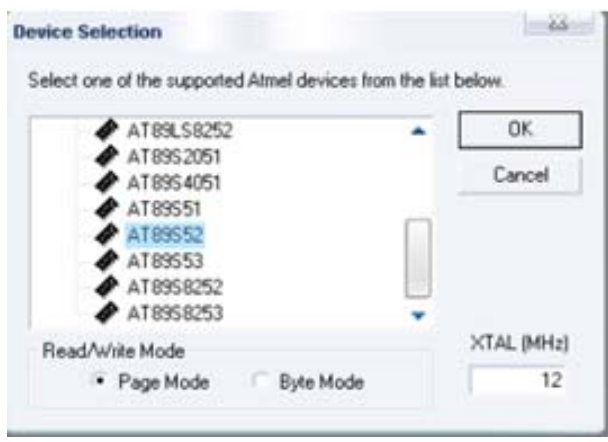

Gambar 11. Pilihan Mikrokontroler Yang Akan Diisi Program.

Selanjutnya pilih page mode untuk pembacaan dan penulisan dari device in page mode (read/write a page at a time). Masukan nilai external clock frekuensi (MHz) penulis menggunakan frekuensi $12 \mathrm{MHz}$. Kemudian klik OK.

Setelah selesai maka dapat dilihat tampilan code buffer. Code buffer ini cocok dengan sistem program flash memori.

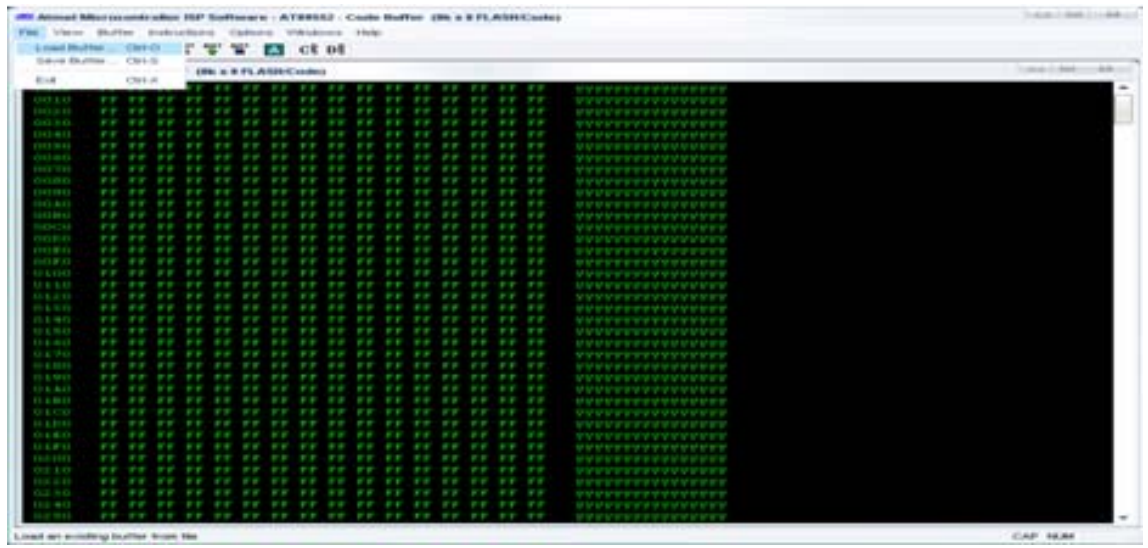

Gambar 12. Pembacaan Data Pada IC Mikrokontroler

Setelah ditentukan programnya, kemudian dapat langsung load program dengan cara pilih load buffer pada file menu. Pilih file HEX program yang akan di masukan pada IC mikrokontroler. 


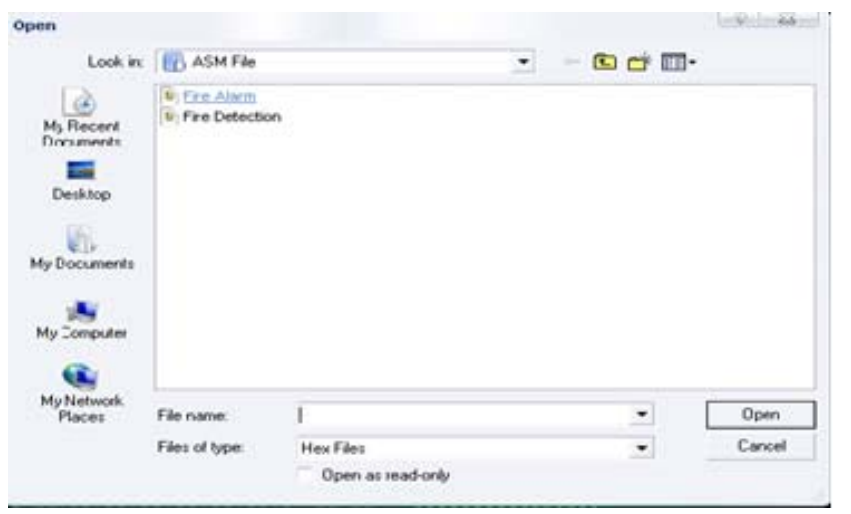

Gambar 13. Open File HEX Dialog.

File.HEX yang telah dimasukan dikenali oleh software tersebut kemudian code buffer akan berubah seperti pada gambar 10 .

\section{Perangkat Lunak Tampilan Monitor}

Langkah - langkah dalam membuat program aplikasi Alarm Detection With GUI adalah :

- Menempatkan komponen yang dibutuhkan pada jendela form menggunakan tools yang ada pada jendela toolbox, atur tata letak komponen.

- Mengatur properti komponen melalui jendela properties

- Menuliskan kode program pada jendela kode, sesuai dengan event suatu kejadian yang akan dirasakan oleh komponen. Misalnya klik dan sebagainya.

Dalam mendesain form tentu tidak lepas dari penggunaan kontrol-kontrol yang ada pada toolbox. Kontrol-kontrol pada visual basic 6.0 tidak hanya ada pada toolbox saja tetapi masih ada kontrol yang tersimpan sebagai tambahan.

\section{1) Form Monitor Alarm Detection With GUI}

Pada form ini akan ditampilkan monitoring Alarm Detection With GUI diantaranya yaitu: denah ruang, indikator alarm pada saat keadaan normal dan pada saat keadaan alarm (kebakaran). Sehingga petugas kebakaran dapat memantau dengan mudah melalui monitor apabila terjadi kebakaran. Untuk membuat tampilan ini, dibutuhkan beberapa kontrol seperti: textbox, label, command button, frame, timer, MSComm, dan lain-lain.Pengaturan dari tiap-tiap kontrol dapat dilihat pada gambar berikut ini: 


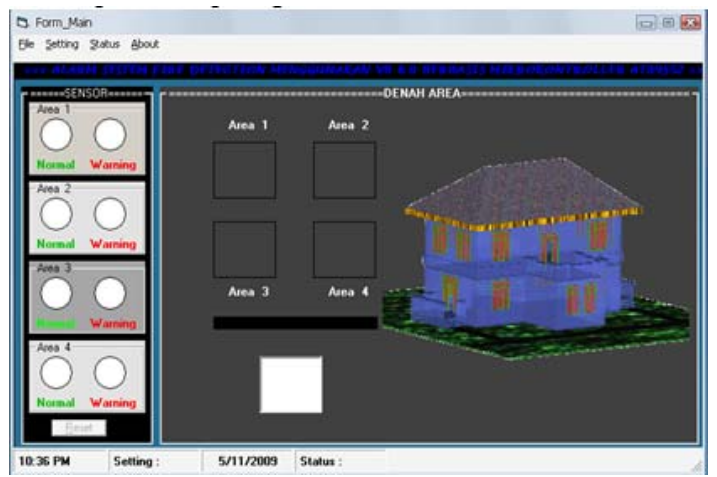

Gambar 14. Form Penempatan Kontrol Untuk Tampilan Alarm Detection With GUI

Pada saat program dijalankan, maka pengguna dapat melihat kondisi pada saat normal, yang ditunjukan dengan warna hijau. Frame yang ada disamping frame sensor asap merupakan denah ruangan. Adapun tampilan dari diagram alir tampilan monitoring pada layar adalah sebagai berikut :

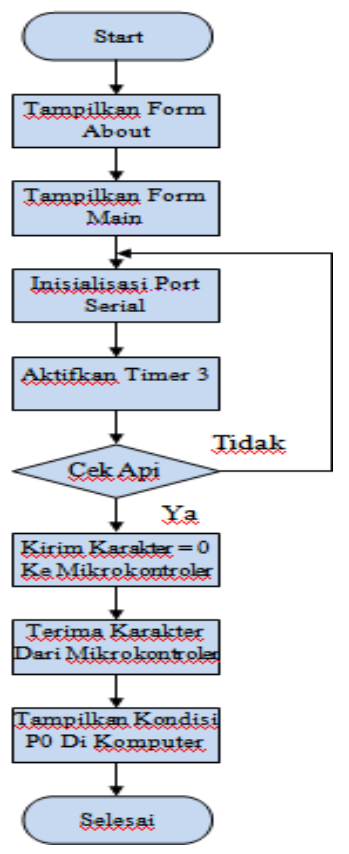

Gambar 15. Diagram alir Pemrograman Tampilan Monitoring 


\section{2) Form Menu}

Form menu merupakan program yang digunakan oleh pengguna (user) untuk mengatur program / data yang dikirim dari mikrokontroler dan keluar dari tampilan visual basic. Form menu terdiri dari 4 bagian, yaitu :

- Menu File Menu file ini digunakan untuk kelur dari tampilan Alarm Detection With GUI.

- Menu Setting Menu setting ini digunakan oleh pengguna (user) untuk mengatur port, bits per second, data bits, parity, stop bits, dan flow control.

- Menu Status Menu status ini digunakan oleh pengguna (user) untuk mengatur koneksi dari rangkaian mikrokontroler ke PC.

- Menu About Menu about ini hanya digunakan untuk menampilkan identitas pembuat.

\section{3) Form Indikator Sensor Asap}

Form indikator sensor asap merupakan program untuk membantu pengguna (user) untuk memantau kondisi sensor asap (Smoke Detector). Pada saat sensor kondisi normal indikator menunjukan tidak ada kebakaran dan ditandai dengan warna hijau, kemudian saat sensor kondisi alarm indikator menunjukan terjadi kebakaran disuatu ruangan dan ditandai dengan warna merah. Langkah-langkah mendesain form indikator sensor asap:

- Tambahkan form ke dalam proyek

- Tambahkan komponen ke dalam form

- Form option terdiri dari 5 frame, 8 label, 8 shape, 1 command.

- Atur propertis komponen melalui jendela properties agar didapat tampilan seperti gambar

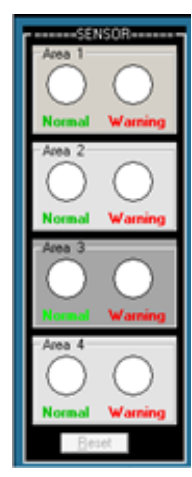

Gambar 16. Indikator Sensor Asap 


\section{KESIMPULAN}

Rancangan tampilan Alarm Detection With GUI menggunakan bahasa pemograman Microsoft Visual Basic 6.0 sebagai simulasi dan bahasa pemograman assembly sebagai program kendali. Rancangan ini mempunyai komponen utama berupa mikrokontroler AT89S52 beserta program sebagai simulasi dari sistem pengiriman informasi berupa tampilan jarak jauh menggunakan media nirkabel. Secara keseluruhan dari hasil pengamatan, percobaan dan pengujian dapat diambil kesimpulan sebagai berikut :

1. Rancangan ini dapat memberikan informasi letak/lokasi tempat terjadinya kebakaran secara real time.

2. Media tampilan ini dapat menampilkan lokasi dan nama ruangan yang terjadi pada saat kebakaran. Yaitu dengan mengisi inisialisasi program pada mikrokontroler dan mengkoneksikan ke bahasa pemograman Visual Basic 6.0 .

\section{PUSTAKA}

1. Atmel, 2007, AT89S52, http://www.atmel.com/dyn resources/doc.0313.pdf (didownload 14 Juli 2009)

2. Arief Ramadhan, (2004), 36 Jam Belajar Komputer Visual Basic 6.0, PT. Elex Media Komputindo

3. Asep Saefullah (2009), Smart Wheeled Robotic yang Mampu Menghindari Rintangan Secara Otomatis, Journal CCIT, Vol.2 No.3

4. Budiharto Widodo (2005), Perancangan Sistem dan Aplikasi Mikrokontroller, Penerbit Erlangga, Jakarta

5. Eko Putra Agfianto (2004), Belajar Mikrokontroller AT89S52 Teori dan Aplikasi, Penerbit ANDI, Yogyakarta

6. Widodo Budiharto, (2005), Perancangan Sistem Dan Aplikasi Mikrokontroller, PT Elek Media Kumputindo, Jakarta.

7. Untung Rahardja, Asep Saefullah, (2009), Simulasi Kendali Kecepatan Mobil Secara Otomatis, Journal CCIT Vol2. No.2 